\title{
Türk Televizyon Yayıncılığında Rekabet İhlali Şikayetlerine Yönelik Nicel Bir Araştırma*
}

\author{
Hüdai Ateş (Arş. Gör.) \\ Ege Üniversitesi IIletişim Fakültesi \\ hudaiates@gmail.com \\ Sefer Kalaman (Dr. Öğr. Üyesi) \\ Bozok Üniversitesi İletişim Fakültesi \\ sefer.kalaman@bozok.edu.tr
}

Başvuru Tarihi: 09.04.2018

Yayına Kabul Tarihi: 25.06.2018

Yayınlanma Tarihi: 30.07.2018

\section{Öz}

İnsanlık tarihinde ticari ilişkilerin başladığı andan bugüne kadar rekabet her daim var olmuştur. Neredeyse bütün sektörlerde yaşanan rekabet, medya sektöründe de farklı şekillerde gerçekleşmiştir. Ancak medya kuruluşları arasında yaşanan bu rekabet, yoğunlaşma, tekelleşme, yakınsama, hakim durumun kötüye kullanılması vb. şekillerde gerçekleşen rekabet ihlallerini de beraberinde getirmiştir. Medya alanında, özellikle de televizyon yayıncllı̆̆ı alanında tüm ülkelerde meydana gelen rekabet ihlalleri Türkiye'de de vuku bulmuş, bu sorun neticesinde rekabet ihlallerini önlemek ve rekabetin dengede tutulmasını sağlamak için Rekabet Kurumu kurulmuştur. Bu noktadan hareketle yapılan çalışmada, televizyon yayıncılığı sektöründe rekabet ihlali ile ilgili Rekabet Kurumu'na yapılan şikayetleri incelemek ve alınan kararların sektöre katkısının ne olduğunu tespit etmek amaçlanmıştır. Bu amaç doğrultusunda bir araştırma yapılmış ve araştırmada nicel araştırma yöntemlerinde biri olan içerik analizi yöntemi kullanılmıştır. Araştırmanın evrenini, rekabet ihlali ile ilgili Rekabet Kurumu'na yapılan şikayet başvuruları oluşturmaktadır. Örneklemi ise Rekabet Kurumu'nun internet sitesindeki 1999-2018 yılları arasındaki televizyon yayıncılığı ile ilgili rekabet ihlaline ait şikayet dosyaları teşkil etmektedir. Araştırma verilerinin analizinden elde edilen sonuçlara göre, gerek verdiği idari para cezası kararlarıyla gerekse de görüş bildirileriyle, Rekabet Kurumu'nun televizyon yayıncılığında denetleyici ve düzenleyici bir etkiye sahip olduğu tespit edilmiştir. Ayrıca, Türkiye'deki televizyon yayıncılığı sektöründe rekabet ihlalinin az sayıda meydana geldiği sonucuna varılmıştır.

Anahtar Kelimeler: Rekabet, Rekabet İhlali, Televizyon Yayıncılı̆̆ı, Rekabet Kurumu.

* Bu çalışma, Selçuk Üniversitesi Sosyal Bilimler Enstitüsü'ne 2018 yılında sunulan “Televizyon Yayın Kuruluşlarında Rekabet İhlali ve Rekabet Kurulu Kararlarının Sektöre Etkisi” başlıklı Yüksek Lisans tezinden türetilmiş makaledir. 
Dissertation Abstract

\title{
A Quantitative Research for the Complaints of Violation of Competition in Turkish Television Broadcasting
}

\author{
Hüdai Ateş (Res. Asst.) \\ Ege University Faculty of Communication \\ hudaiates@gmail.com \\ Sefer Kalaman (Asst. Prof. Dr.) \\ Bozok University Faculty of Communication \\ sefer.kalaman@bozok.edu.tr
}

Date Received: 09.04.2018

Date Accepted: 25.06.2018

Date Published: 30.07.2018

\begin{abstract}
Competition has always existed from present to the moment which commercial relations begin in history of humanity. Competition which in almost occured all sectors has taken place in different forms in the media sector. However, this competition among media organizations brought about violations of competition which occured concentration, monopolization, convergence, abuse of dominant position. Violations of competition which occurring in the media, has taken place both in all countries and in Turkey. Therefore, Competition Authority was established to prevent violations of competition and ensure that competition is balanced. In the study, it was aimed to examine the complaints made to the Competition Authority regarding the violation of competition in the television publishing sector and to determine what is the contribution of the decisions to sector. For this purpose, a research has been made to reveal the violations of competition and the sectoral effect of the Competition Authority. Content analysis method which is one of the quantitative research methods was used in the research. The population of the research constitutes complaints made to the Competition Authority concerning violations of competition. The sample is the complaint files of violations of competition related to the television publishing between 1999-2018 of the website of the Competition Authority. According to the results obtained from the analysis of the research data, competition Authority has a supervisory and regulatory influence on television broadcasting with its administrative fines and opinions. In addition, violation of competition in the television broadcasting sector in Turkey has concluded that a small number.
\end{abstract}

Keywords: Competition, Violation of Competition, Television Broadcasting, Competition Authority. 


\section{Giriş}

Teknolojik imkanların artması ve dünyanın gerek fiziki gerekse de sanal boyutta daha kolay erişilebilir bir yapıya bürünmesi, hayatı kolaylaştırmış ancak aynı zamanda ayakta kalmak için gereken mücadele gücüne olan ihtiyacın artmasına da neden olmuştur. Bundan dolayı gerek şahıslar gerekse de tüzel kişiler için hedefe ulaşabilmek ve başarıya sahip olabilmek büyük önem arz etmektedir. Nitekim bu arzular, güçlü olma isteği, azim, hırs gibi duyguları da beraberinde getirmekte ve dolayısıyla, her ne kadar tarzı ve formatı, şahıslarda ve tüzel kişilerde farklılık gösterse de, kendisiyle benzer faaliyetler gösterenlerden geri kalmamak için çaba sarf etmek olan rekabetin ortaya çıkmasına sebep olmaktadır.

Hayatın hemen hemen her noktasında var olan rekabet, zaman içerisinde farklı ülkelerde, toplumlarda ve dillerde farklı anlamlara gelmiş ve rekabete farklı zaman dilimlerinde çeşitli anlamlar yüklenmiştir. Türkçe ekseninde ele alındığında rekabetin, aslı itibariyle Hami-Sami dil ailesi kökenine dayanan Arapça kökenli bir kelime olduğu ortaya çıkmaktadır. Rekabet, Arapça'da "Ar-Rakkaba" olarak geçmekte ve "denetleme, kontrol etme" anlamında kullanılmaktadır. Tarihte eski kullanımları bulunan rekabet kelimesinin yazılı olarak ilk ele alındığı metin ise 1680 Meninski, Thesaurus'dur. Burada "yıldızları gözetlemek" anlamında kullanılan kelime daha sonra Kamus-ı Türki'de (1900), "meslek veya sanatta yarışma, bir şeyi elde etmek için başkasıyla mücadele etme" anlamında kullanılmıștır. Kamus-ı Türki' den şekillenerek günümüzdeki anlamına ulaşan rekabet kavramı, "bir alanda ve faaliyette benzeri kişilerden geri kalmama gayreti” olarak kullanılmaktadır (Şafak, 1992, 473). İktisadi açıdan ele alındığında ise rekabeti, ticari alanda rakipler arasında diğerlerinden öne geçme ve iktisadi başarı sağlama amacıyla yapılan yarışma olarak ifade etmek mümkündür (Edgü, 1967, 136).

İnsan hayatında, eğitim, spor, siyaset, ticaret, ekonomi, sanat, medya ve daha birçok alanda farklı şekillerde ve farklı boyutlarda vuku bulan rekabet, bir taraftan yapılan işin kalitesini arttırmak için elzem bir unsuru oluştururken bir taraftan da kazanç elde etmek için haksız eylemler neticesinde bir tarafın kayba uğramasına yahut noksan kalmasına hizmet edebilmektedir. Bu durumdan ötürü rekabetin doğru usullerde gerçekleştirilip, rekabetin yaşandığı alanlardaki kaliteyi ve kazanımları arttırabilmek ve rekabetin engellenmesiyle gerçekleşecek zararların önüne geçebilmek için tüm dünya ülkeleri hukuk sistemlerinde rekabetin kuralarını kanun nezdinde düzenlemiştir.

Bu ülkeler, rekabetin korunması ve kurallarının belirlenmesi için rekabet hukukunu oluşturmuşlardır. Günümüz itibariyle rekabet hukuku üç hukuki düzen üzerine oturtulmuştur: Amerikan rekabet hukuku sistemi, İngiliz rekabet hukuku sistemi ve Avrupa Birliği rekabet hukuku sistemi. Amerikan rekabet hukuku sistemi, çoğunluk olarak yargısal bir niteliğe sahiptir. İngiliz rekabet hukuku sistemi de idari olarak şekillenmiştir. Avrupa Birliği rekabet hukuku sistemi ise hem hukuki hem de idari sistemi kapsayan geniş bir hukuk sistemi üzerine kurulmuştur (Utton, 2003, 55). $\mathrm{Bu}$ rekabet hukuku sistemlerinin en eskisi Amerikan rekabet hukuku sistemdir. Amerika'da 1890 yılında Sherman Antitröst Yasası adında çıkarılan yasa ile tekelleşmeyi önlemek amaçlanmış ve bu yasa ile rekabet hukukunun temeli atılmıştır (Stern, 2018, 1). Türk rekabet hukuk sistemi tasarlanırken bu üç hukuk sisteminden de yararlanılmıştır ancak Türk rekabet hukuku sistemi bu hukuk sistemleri arasında yapısı itibariyle en fazla Avrupa Birliği rekabet hukuku sistemine benzemektedir. 
Türkiye, Türkiye Cumhuriyeti Anayasasının 167. maddesinde yer alan "Devlet, para, kredi, sermaye, mal ve hizmet piyasalarının sağlıklı ve düzenli işlemelerini sağlayıcı ve geliştirici tedbirleri alır; piyasalarda fiili veya anlaşma sonucu doğacak tekelleșme ve kartelleşmeyi önler. Dış ticaretin ülke ekonomisinin yararına olmak üzere düzenlenmesi amacıyla ithalat, ihracat ve diğer dış ticaret işlemleri üzerine vergi ve benzeri yükümlülükler dışında ek mali yükümlülükler koymaya ve bunları kaldırmaya kanunla Bakanlar Kuruluna yetki verilebilir" ibaresine istinaden (Mevzuat, 2018, 173) devleti rekabet hukukuna ilişkin düzenlemeler yapmakla yükümlü kılmıştır. Bunun haricinde 1963 yılında Avrupa Ekonomik Topluluğu ile yapılan Ankara Anlaşması'nın 16. maddesinde yer alan “Akit Taraflar, Topluluğu kuran Antlaşma'nın üçüncü büyük bölümünün 1. kısmında yer alan rekabet, vergileme ve mevzuatın yaklaştırılması ile ilgili hükümlerde anılan ilkelerin, ortaklık ilişkilerinde uygulanması gerektiğini kabul ederler" ibaresi de Türkiye'yi rekabet alanında çalışmalar yapmaya yönlendirmiştir (Dışişleri Bakanlığl, 2018).

Sonrasında 1975 yılında Ticaret Bakanlığı, "Ticaretin Düzenlenmesi ve Tüketicinin Korunması Hakkında Kanun Tasarısı" adı altında bir tasarı hazırlamıştır. 1978 yılında da "İç ve Dış Ticaretin Düzenlenmesi Hakkında Kanun Tasarısı" meclise sunulmuştur. 1980 yılında yine "Ticarette Dürüstlüğün Korunması Hakkında Kanun Tasarısı" ve ardından da 1981 yılında "Ticari Faaliyetlerin Düzenlenmesi ve Tüketicinin Korunması Hakkındaki Kanun Tasarısı" ve son olarak da 1983 yılında "Tüketicinin korunması Hakkında Kanun Tasarısı" meclise sunulmuştur. Ancak bu yasa tasarılarının hiçbiri yasalaştırılamamıştır (Sanlı, 2000, 22). Ardından Sanayi ve Ticaret Bakanlığı'nda oluşturulan bir komisyon, Rekabetin Korunması Hakkında Kanun Tasarısını hazırlamış ve 1994 yılında 4054 nolu Rekabetin Korunması Hakkında Kanun yürürlüğe girmiştir. Rekabetin Korunması Hakkında Kanun'un yürürlüğe girmesinden sonra ise 1997 yllında bu kanunu uygulamakla yükümlü otorite olan Rekabet Kurumu tesis edilmiştir (Rekabet Kurumu, 2018a).

Rekabet Kurumu, 4054 Sayllı Kanun'un 20’nci maddesine göre mal ve hizmet piyasalarının serbest ve sağlıklı bir rekabet ortamı içinde teşekkülünün ve gelişmesinin temini ile bu Kanunun uygulanmasını gözetmek ve Kanunun kendisine verdiği görevleri yerine getirmek üzere kurulmuştur. Bu çerçevede Rekabet Kurumu'nun esas görevi Kanun'da kendisine verilen yetkileri kullanarak mal ve hizmet piyasalarındaki rekabetçi sürecin tehdit edilmesini engellemektedir. Rekabetçi sürecin korunması yoluyla kaynakların etkin dağılımının sağlanması, toplumsal refahın arttırılması, Rekabet Kurumu'nun misyonunun temel dayanağını oluşturmaktadır (Rekabet Kurumu, 2018b).

Rekabet Kurumu, kanunun öngördüğü şekilde, rekabet konusunda mevcut yapıyı düzenlemek ve yürütmek için kurulmuş bir organdır. Rekabet Kurumu, rekabetin gerçekleştiği bütün iş alanlarını düzenleyen bir mahiyete sahip olmaktadır. Rekabet Kurumu, gıda, turizm, tekstil, inşaat vb. birçok iş sektöründeki rekabeti düzenleyen ve açılan davaları karara bağlayan bir organdır. Rekabet Kurumu, genel çerçevede bu davaları ve dolayısıyla rekabeti beş alanda ele alıp sınırlandırmaktadır. Bu alanlar, "birleşme ve devralma”, "menfi tespit ve muafiyet”, "özelleştirme”, "rekabet ihlali" ve "diğer" olarak kategorileştirilmiştir.

Rekabet Kurumu'nun rekabet ortamını tesis ettiği ve rekabeti engelleyen durumlarda müdahale ettiği bu alanların en önemlilerinden bir tanesi de kuşkusuz 
medya sektörüdür. Medya sektöründe ise rekabetin en çok yaşandığı alan kuşkusuz televizyon yayıncılığı alanıdır. Öyle ki, 1990'lı yılların başından itibaren Türkiye'deki televizyon yayıncılığı sektöründe meydana gelen rekabet, her geçen yıl daha da artarak devam etmiştir. Gerek ulusal, gerekse uluslararası pazarlarda sektöre girme çabaları beraberinde yoğun bir rekabet ortamını getirmiştir. Medya sektörü ve bu ortamın en önemli alanlarından biri olan televizyon yayıncılığı sektörü birçok sektörlerden farklı olarak kendi iç dinamiklerini belirleyerek, sektörde var olabilme ve sektöre girebilme şartlarını "büyük olanların" lehine çevirmiștir. Özellikle televizyon yayıncılığı sektörü denildiğinde büyük ve güçlü olanların daha da büyüdüğü, küçüklerin ise sektöre girme şansı dahi bulamadığı bir ortam oluşmuştur (Sayılgan, 2009, 80).

$\mathrm{Bu}$ şirketler temelde üç şey için rekabet etmektedir. Birincisi, içerik için (ki bu müşterilerine satacakları şeydir), ikincisi, bu içeriğin müşterilere en iyi yoldan ulaştırılması için ve üçüncüsü de asıl ulaşmak ve sahip olmak istedikleri şey için yani müşterinin kendisi için rekabet etmektedir (Pereira, 2003, 3-4). Ancak Türkiye'deki televizyon kanalları bu amaçlar doğrultusunda, sektörde hakim duruma gelmek, daha fazla kazanç ya da gelir elde etmek, varlığını daim kılmak vb. durumlar için rekabeti ihlal edebilmektedir. Bu rekabet ihlalleri, yoğunlaşma, hakim durumun kötüye kullanılması, yakınsama ve tekelleşme şeklinde gerçekleşebilmektedir.

Bu sorundan hareketle hazırlanan çalışmada, Türkiye'deki televizyon yayıncılığı sektöründe rekabet ihlali ile ilgili Rekabet Kurumu'na yapılan şikayetleri incelemek ve Rekabet Kurumu tarafından alınan kararların sektöre katkısının ne olduğunu tespit etmek amaçlanmıştır. Çalışma, Rekabet Kurumu'nun rekabet ihlali konusunda aldığı kararlarla televizyon yayıncılığı sektörüne nasıl etki ettiğini tespit edecek olması, rekabet ihlallerini hangi kurum ve kuruluşların gerçekleştirdiğini ortaya çıkaracak olması ve televizyon yayıncılı̆̆ sektöründe ihlallerin hangi düzeyde olduğunu açıklayacak olması açısından önem arz eden bir yapıya sahip olmaktadır.

Çalışmada, Türkiye'deki televizyon yayıncılığının rekabet ihlali konusundaki durumunu ortaya çıkarmak için bir araştırma yapılmıştır. Araştırmada nicel araştırma yöntemlerinden biri olan içerik analizi kullanılmıştır. Araştırmanın evrenini, rekabet ihlali ile ilgili 1999-2018yılları arasında Rekabet Kurumu'na yapılan 2 bin 757 şikayet dosyası oluşturmaktadır. Bu şikayet dosyaları, rekabet ihlali ile ilgili Türkiye'deki bütün iş alanlarına ait olan şikayetleri içermektedir. İlgili yıllar arasında televizyon yayıncılığı sektörü ile ilgili rekabet ihlali konusunda sadece 25 şikayet dosyası mevcut bulunmaktadır. Bu nedenle araştırmanın örneklemini, Rekabet Kurumu'nun internet sitesindeki 1999-2018 yılları arasındaki televizyon yayıncılığı ile ilgili rekabet ihlaline ait 25 şikayet dosyası teşkil etmektedir. Rekabet Kurumu'nun dijital arşivi kullanılarak elde edilen rekabet ihlali dava dosyaları, kodlama formu aracılığıyla kodlanmış ve istatistik programı aracılığıyla da analiz edilmiştir.

\section{Araştırmanın Metodolojisi}

\subsection{Araştırmanın Amacı, Önemi ve Literatüre Katkısı}

Çalışmada, Türkiye'deki televizyon yayıncılığı sektöründe rekabet ihlali ile ilgili Rekabet Kurumu'na yapılan şikayetleri incelemek ve alınan kararların sektöre katkısının ne olduğunu tespit etmek amaçlanmıştır. Türkiye'deki televizyon yayıncılığı için elzem konulardan biri olan rekabetihlali konusu, Türkiye'nin en önemli kurumlarından biri olan Rekabet Kurumu çerçevesinde ele alınıp incelenmiştir. 
Kuşkusuz, gelişmenin önünü açması, bireyleri ve şirketleri daha yaratıcı olmaya itmesi, toplumsal refahı arttırması ve kaynakların doğru olarak kullanılması için rekabetin varlığı son derece önemlidir. Kaliteli bir rekabet ortamı oluşturulabilmesi de ancak rekabet hukuku kurallarına uyulmasıyla mümkün olmaktadır. Rekabet hukuku ile şirketlerin hukuki faaliyetlerinin düzenlenmesi ve bu sayede rekabetçi sürecin daima güçlü tutulması gerekmektedir. $\mathrm{Bu}$ nedenlerden ötürü yapılan çalışma, Rekabet Kurumu'nun rekabet ihlali konusunda aldığı kararlarla televizyon yayıncılığı sektörüne nasıl etki ettiğini tespit edecek olması, rekabet ihlallerini hangi kurum ve kuruluşların gerçekleştirdiğini ortaya çıkaracak olması ve televizyon yayıncılığı sektöründe ihlallerin hangi düzeyde olduğunu açıklayacak olması açısından önem arz etmektedir.

Bununla birlikte, konu ile ilgili yapılan çalışmaların sayısının az olması, bu alanın daha fazla incelenmesi ihtiyacını doğurmaktadır. Bu noktada yapılan çalışma alana katkı sağlayacak ve ileride yapılacak diğer bilimsel çalışmalara da veri oluşturacaktır.

\subsection{Araştırmanın Yöntemi, Sınırlıııkları ve Hipotezleri}

Çalışmada, hedeflenen amaca ulaşmak için bir araştırma yapılmış ve araştırmada nicel araștırma yöntemlerinden biri olan içerik analizi kullanılmıştır. Araştırmada televizyon yayıncılığı ile ilgili rekabet ihlali soruşturma dosyalarına erişmek için Rekabet Kurumu'nun dijital arşivinden yararlanılmıştır. Soruşturma dosyalarını/ kurul kararlarını analize hazır hale getirmek ve verileri düzenlemek amacıyla öncelikle kategoriler oluşturulmuş, sonrasında ise kategoriler dahilinde kodlama formu hazırlanmıştır. Kodlanan veriler SPSS 20 (Statistical Package for the Social Sciences) adlı istatistik paket programı aracılığıyla analiz edilmiştir.

Rekabet Kurumu genel çerçevede davaları beş alanda ele alıp sınırlandırmaktadır. $\mathrm{Bu}$ alanlar, "birleşme ve devralma", "menfi tespit ve muafiyet", “özelleştirme", "rekabet ihlali" ve "diğer" olarak kategorileştirilmiştir. Çalışmada, bu alanlardan sadece "rekabet ihlali" alanı incelenmeye alınmıştır. Bu doğrultuda araştırmanın evrenini de, rekabet ihlali ile ilgili 1999-2018 yılları arasında Rekabet Kurumu'na yapılan 2 bin 757 şikayet dosyası oluşturmaktadır. Bu şikayet dosyaları, rekabet ihlali ile ilgili Türkiye'deki bütün iş alanlarına (gıda, taşımacılık, turizm, gazetecilik vb.) ait olan şikayetleri içermektedir. $\mathrm{Bu}$ iş alanlarından birisi ise televizyon yayıncılığı sektörüdür. İlgili yıllar arasında televizyon yayıncılığı sektörü ile ilgili rekabet ihlali konusunda sadece 25 şikayet dosyası mevcut bulunmaktadır. $\mathrm{Bu}$ nedenle araştırmanın örneklemini, Rekabet Kurumu'nun internet sitesindeki 19992018 yılları arasındaki televizyon yayıncılı̆̆ı ile ilgili rekabet ihlaline ait 25 şikayet dosyası teşkil etmektedir. Rekabet Kurumunun halihazırda 1997 yılında kurulmuş olmasından ve Rekabet Kurumu'nun dijital arşivinde 1999 yılından önceki şikayet dosyalarının paylaşılma açılmamış olmasından dolayı, örnekleme 1999 yılı ve sonrasındaki şikayet dosyaları dahil edilmiştir.

$\mathrm{Bu}$ minvalde hazırlanmış olan çalışmada, araştırmanın hipotezleri şu şekilde belirlenmiştir:

- H1: Rekabet Kurumu, televizyon yayıncilığı sektöründe rekabet sürecini denetleyici ve düzenleyici bir rol üstlenmektedir.

- H2: Rekabet ihlali ile ilgili şikayet edilenler daha çok özel kanallardır.

- H3: Rekabet Kurumu, şeffaflık ve alenilik ilkesine göre hareket etmektedir. 


\section{Bulgular}

Türkiye'deki televizyon yayıncılığı sektöründe rekabet ihlali ile ilgili Rekabet Kurumu'na yapılan şikayetlerin ele alındığı çalışmada, şikayet dosyaları incelenmiş ve kodlama formu aracılığıyla kodlanmıştır. Örnek teşkil etmesi açısından, kodlanan dava dosyalarından birine çalışmada yer verilmiştir.

Tablo 1: Televizyon Yayıncılığı Sektöründeki Rekabet İhlali İle İlgili Örnek Dava

\begin{tabular}{|c|c|}
\hline Dava Karar No & $\mathrm{SR} / 02-4$ \\
\hline Davanın Tarihi & 28.8.2002 \\
\hline Şikayette Bulunan & $\begin{array}{l}\text { Star Digital İletişim Anonim Şirketi } \\
\text { Star Televizyon Hizmetleri Anonim Şirketi }\end{array}$ \\
\hline Şikayet Edilen & $\begin{array}{l}\text { Türkiye Futbol Federasyonu } \\
\text { Digital Platform İletişim Hizmetleri Anonim Şirketi } \\
\text { Atlas Yayıncılık ve Ticaret Anonim Şirketi }\end{array}$ \\
\hline Karar Dosyasının Sayfa Sayısı & 40 \\
\hline İncelenen Belgeler & Tamamı Yayınlanmış \\
\hline Davanın Konusu & $\begin{array}{l}\text { TFF'nin 1. Lig futbol maçları yayın hakları } \\
\text { ihalesinde, ihaleye katılabilecek sayısal } \\
\text { uydu platformu işleticileri arasında ayrımcılık } \\
\text { yapmak suretiyle rekabeti engellemesi. } \\
\text { Dijitürk ve Atlas'ın TFF'nin açtığı ihaleyi hukuka } \\
\text { aykırı olarak kazanması, 1. Lig futbol maçları yayın } \\
\text { hakları pazarında yayın tekeline sahip olduğu ve } \\
\text { haber amaçlı görüntü talep eden diğer kanallara } \\
\text { ihale şartnamesine aykırı hareket etmesi. }\end{array}$ \\
\hline Kararın Özeti & $\begin{array}{l}4054 \text { sayılı kanunun 4. maddesi kapsamında } \\
\text { Türkiye Futbol Federasyonu tarafından } \\
\text { bir ihlalin gerçekleştirilmediğine, } \\
\text { Hak sahibi kuruluşlar Digitürk ve Atlas'ın, } 4054 \text { sayılı } \\
\text { kanunun } 6 \text {. maddesine göre hakim durumun kötüye } \\
\text { kullanılmasına uygunluk gösteren uygulamalarından } \\
\text { ötürü kanunun 16. maddesi uyarınca idari para } \\
\text { cezası ile cezalandırımalarına karar verilmiştir. }\end{array}$ \\
\hline Sonuç & Oy birliği ile Kabul \\
\hline
\end{tabular}

Türkiye'deki televizyon yayıncılığı alanında rekabet ihlaline dair Rekabet Kurumu'na açılan 25 dava dosyasından elde edilen veriler analiz edilmiştir. Çalışmada, analizden elde edilen sonuçlar tablolaştırılmış ve yorumlanmıștır.

Tablo 2: Rekabet İhlali İle İlgili Yapılan Şikayetlerin Yıllara Göre Dağılımı

\begin{tabular}{|l|l|c|c|}
\hline & Kategoriler & Sayı & $\%$ \\
\hline \multirow{5}{*}{ Şikayet Yılı } & $1999-2002$ & 6 & 24,0 \\
\cline { 2 - 4 } & $2003-2006$ & 5 & 20,0 \\
\cline { 2 - 4 } & $2007-2010$ & 5 & 20,0 \\
\cline { 2 - 4 } & $2011-2014$ & 5 & 20,0 \\
\cline { 2 - 5 } & $2015-2018$ & 4 & 16,0 \\
\cline { 2 - 4 } & Toplam & 25 & 100,0 \\
\hline
\end{tabular}

Araştırma kapsamında incelenen rekabet ihlali davaların yıllara göre dağılımına bakıldığında, davaların \%24,0'ünün 1999-2002 yılları arasında, \%20'sinin 20032006 yılları arasında, \%20'sinin 2007-2010 yılları arasında, yine \%20'sinin 2011-2014 yılları arasında ve \%16'sının da 2015-2018 yılları arasında açıldığı 
görülmektedir (Tablo 2). Dörder yıllık olarak kategorileștirilen verilere bakıldığında, yıllara göre kısmen az sayıda artış ve düşüşler gerçekleşse de, değerlerin birbirlerine oranları arasında, hem düşüş hem de artışlar bakımından dikkat çekecek düzeyde büyük farklılıklar görülmemektedir. Buna göre, genel çerçevede yıllar bazında açılan davaların sayısının birbirine yakın olduğunu söylemek mümkündür.

Tablo 3: Rekabet İhlali İle İlgili Yapılan Şikayetlerin Şikayet Edenlere Göre Dağılımı

\begin{tabular}{|l|l|l|l|}
\hline & Kategoriler & Sayı & $\%$ \\
\hline \multirow{5}{*}{ Şikayet Eden } & Res'en & 1 & 2,5 \\
\cline { 2 - 4 } & Şahıs & 2 & 5,0 \\
\cline { 2 - 4 } & Şirket & 29 & 72,5 \\
\cline { 2 - 4 } & Meslek Birliği & 2 & 5,0 \\
\cline { 2 - 4 } & Gizli & 4 & 10,0 \\
\cline { 2 - 4 } & Diğer & 2 & 5,0 \\
\cline { 2 - 4 } & Toplam & 40 & 100,0 \\
\hline
\end{tabular}

Analizden elde edilen sonuçlara göre, televizyon yayıncılığı sektöründeki rekabet ihlali ile ilgili açılan 25 davada şikayetçi olan taraf sayısı 40 olarak tespit edilmiştir. Şikayet dosyalarının bazılarında bir şikayetçi mevcutken bazı dosyalarda ise birden fazla şikayetçi bulunmakta ve bu şikayetçiler topyekun bir kurum ya da kuruluştan şikayetçi olabilmektedir. Araştırma verilerinin analizinden elde edilen sonuçlara göre, şikayetçi olanların \%2,5'inin re'sen, \%5'inin şahıs, \%72,5'inin şirket, \%5'inin meslek birliği, \%10’unun gizli, \%5'inin de diğer statülerde şikayetçi olduğu görülmektedir (Tablo 3).

Rekabet ihlalinin gerçekleştiği iddiasıyla en fazla şikayetçi olan tarafın şirketler olduğu tespit edilmiştir. Bu durum, şirketlerin rekabet ihlalleri söz konusu olduğunda gelir kaybına uğramamak için çok daha fazla hassas hareket ettiklerini göstermektedir. Çünkü rekabet ortamının sağlanması, bu şirketlerin ayakta kalmalarına hizmet etmektedir. Türkiye'de rekabet ihlali konularında Rekabet Kurumu, tekelleşme ve kartelleşmenin önüne geçmede önemli bir rol oynadığı için şirketlere güven vermektedir. Bu da kuruma yapılan şikayetlerde şirketlerin sayıca fazla olmasının sebeplerinden biri olmaktadır. Res'en, şahıs, meslek birlikleri, gizli ve diğer kategorilerinin daha az soruşturma başvurusunda bulunmaları ekonomik endişelerinin şirketlere göre daha az olmasından kaynaklanmaktadır. Ayrıca şirketlerin, piyasada var olabilme mücadelelerini mahkemelerin yanı sıra Rekabet Kurumu aracılığıyla da hukuki yollara başvurarak sürdürdüklerini söylemek mümkündür.

Bunların haricinde rekabet ihlali davalarında 'gizli' olarak şikayetçi olanların oranının da genele bakıldığında dikkate değer bir düzeyde olduğu görülmemektedir. Aslı itibariyle bu tür davalarda şikayetçi olanlar kimliklerini gizlemekten çok kimliklerinin açıkça belirtmeleri taraftarı olmaktadır ancak bazı hususi davalarda usul gereği ya da şikayetçi olanı korumak için kimliğin gizlenmesi durumu gerçekleşebilmektedir. Gizli yapılan şikayetlerin başvuruları incelendiğinde bu şikayetlerin \%50'lik kısmının ihbarla gerçekleştiği, \%50'lik kısmının ise şikayet başvurularındaki bilgiler doğrultusunda rekabet kurumu içerisindeki uzman kişiler tarafından yapıldığı tespit edilmiştir. Öyle ki, Rekabet kurumunda açılan bir davada 11-45/1034-354 numaralı soruşturma dosyasının şikayette bulunan kısmında "Res'en" ve "Gizlilik talebi bulunmaktadır" ibareleri aynı anda yer almaktadır. Buna göre, kurum içerisindeki 
uzmanların dahi şikayet talebinde bulunduklarında isimlerini gizleme isteğinde olabildikleri görülmektedir. Buna ek olarak ihbar ile yapılan şikayetlerde de, şikayet edenlerin daha sonra karşılaşabilecekleri maddi veya manevi mücadelelerden kaçınmak için kimliklerini gizlediklerini söylemek mümkündür.

Tablo 4: Rekabet İhlali İle İlgili Yapılan Şikayetlerin Şikayet Edilenlere Göre Dağılımı

\begin{tabular}{|l|l|l|l|}
\hline & Kategoriler & Sayı & $\%$ \\
\hline \multirow{5}{*}{ Şikayet Edilen } & Devlet Kanalı & 2 & 2,8 \\
\cline { 2 - 4 } & Özel Kanallar & 54 & 76,1 \\
\cline { 2 - 4 } & TFF & 5 & 7,0 \\
\cline { 2 - 4 } & RTÜK & 1 & 1,4 \\
\cline { 2 - 4 } & Meslek Birliği & 9 & 12,7 \\
\cline { 2 - 4 } & Diğer & 0 & 0 \\
\cline { 2 - 4 } & Toplam & 71 & 100,0 \\
\hline
\end{tabular}

Çalışmaya dahil olan dosyalarda kimin şikayet edildiği incelendiğinde ise, şikayet eden tarafta olan durum tekrarlanmıştır. Öyle ki, 25 dava dosyası olmasına rağmen 71 kurum ya da kuruluş şikayet edilmiştir. Çünkü rekabet ihlali ile ilgili bazı dosyalarda Türkiye'deki 3 ya da 4 kuruluş topyekun şikayet edilmiştir. Türkiye'nin televizyonla ilişkili olan farklı mecralardaki kurum ya da kuruluşlarına yöneltilen şikayetler incelendiğinde, şikayet edilenlerin \%2,8'inin devlet kanalı, \%76,1'inin özel kanallar, \%7'sinin Türkiye Futbol Federasyonu, \%1,4'ünün Radyo Televizyon Üst Kurulu ve \%12,7'sinin de meslek birliği olduğu görülmektedir (Tablo 4).

Şikayet edilme oranına bakıldığında en çok şikayet edilenlerin özel kanallar olarak tespit edilirken, bunu meslek birlikleri ve Türkiye Futbol Federasyonu takip etmektedir. En az şikayet edilenler ise önce RTÜK ardından ise devlet kanalları olmaktadır. Özel kanalların gelir kaynaklarının devlet kanallarına göre farklılık göstermesi, mevcut durumun sebeplerinin başında gelmektedir. Çünkü özel kanalların faaliyet sürdürebilmesi için ihtiyaç duydukları temel gelir kaynağı reklamlardır. Bu da dolayısıyla piyasadaki rekabet ihlali oranlarını artırmaktadır. Nitekim dosyalarda şikayette bulunanların çoğunluğunun da yine özel kanallar olduğu gözlemlenmiștir. Bu doğrultuda daha fazla gelir elde etmek ve rekabette geri kalmak istemeyen özel kanalların, temel yayın politikalarını 'en çok izlenen olmak' olarak belirlediklerini ve dolayısıyla kamu yararını göz ardı edebildiklerini ifade etmek mümkündür.

En düşük şikayet oranlarına sahip olan RTÜK ve devlet kanallarının ise böyle bir orana sahip olması şaşırtıcı olmamaktadır. Nitekim bu kurumların gelir kaynakları özel kanallarınkilerle aynı değildir. Reklam geliri endişesi olmayan bu kurumların dolayısıyla rekabet ihlali yapma oranı da düşük olmaktadır. Yine bununla beraber bu kurumların önceliklerinin kamu yararı olduğu, faaliyet süreçlerinde çok daha hassas oldukları ve hata paylarının daha düșük olduğu da bilinmektedir. Öyle ki, RTÜK ve devlet kanallarına soruşturma açılmasına dair verilen kararların tamamı ret ile sonuçlanmıştır. 
Tablo 5: Dava Dosyalarının Sayfa Sayısına Göre Dağılımı

\begin{tabular}{|l|l|l|l|}
\hline & Kategoriler & Sayı & $\%$ \\
\hline \multirow{5}{*}{ Dosya Sayfa Sayısı } & $1-7$ & 10 & 40,0 \\
\cline { 2 - 4 } & $8-14$ & 5 & 20,0 \\
\cline { 2 - 4 } & $15-21$ & 1 & 4,0 \\
\cline { 2 - 4 } & $22-28$ & 3 & 12,0 \\
\cline { 2 - 4 } & $29-35$ & 0 & 0 \\
\cline { 2 - 4 } & $36-42$ & 3 & 12,0 \\
\cline { 2 - 4 } & $43+$ & 3 & 12,0 \\
\cline { 2 - 4 } & Toplam & 25 & 100,0 \\
\hline
\end{tabular}

Rekabet ihlaline dair Rekabet Kurumu'na açlan davaların sayfa sayısına göre dağılımına bakıldığında ise, dava dosyalarının \%40'ının 1-7, \%20'sinin 8-14, \%4'ünün 15-21, \%12'sinin 22-28, yine \%12'sinin 36-42 ve \%12'sinin de 43 ve üzeri sayfa sayısına sahip olduğu görülmektedir (Tablo 5). Verilere göre davaların \%60'ı en fazla 14 sayfadan oluşmaktadır. Burada dikkat çeken nokta, davada taraf olan kurum ve kuruluşların sayısı arttıkça ve rekabet ihlalinin gerçekleşmiş olması muhtemel görüldükçe davaların sayfa sayıları da artış göstermektedir.

Tablo 6: Dava Dosyalarının Alenilik Düzeyi

\begin{tabular}{|l|l|l|l|}
\hline & Kategoriler & Sayı & $\%$ \\
\hline \multirow{3}{*}{ Bilgi Paylaşımı } & Tamamı Yayınlanmış & 16 & 64,0 \\
\cline { 2 - 4 } & Kısıtlı (Ticari Sır) & 9 & 36,0 \\
\cline { 2 - 4 } & Toplam & 25 & 100,0 \\
\hline
\end{tabular}

Şikayet dosyalarının ne oranda aleni olduğu ve ne oranda kısmı olarak kısıtlamaya uğratıldığı incelendiğinde, dosyaların \%64'ünün olduğu gibi tamamen yayınlandığı, \%36’sının ise kısıtlandığı veya ticari sır olarak addedilip kısmen gizlendiği görülmektedir (Tablo 6).

Dosyalar incelendiğinde yayınlanmayan bilgilerin çoğunlukla, şirketlerin abonelerinden elde ettikleri gelirlere, abone/müşteri sayılarına, firmaların satış için yaptıkları görüşmelerdeki satış temsilcilerinin ve müşterilerin isimlerine, satışı söz konusu olan ürünlerin isimlerine, şirketlerin pazar paylarına, şirketler arasında yapılan yazışma konuları ve detayları ile ödeme planlamalarına, şikayete konu olan kurumun faaliyetine göre reyting ölçümlerinin yapıldığı il, ilçe ve hane sayılarına, şikayete konu olan televizyon programlarının isimlerine, yapılması planlanan yayınlarla ilgili özel isimlere (futbol takımlarının isimleri gibi), şirketler arasındaki anlaşmalardaki teklif metinlerinin konularına, yazışmaların hangi isimler arasında yapıldığına, ticari sırlara ve verilen para cezalarına dair olduğu tespit edilmiştir.

Tablo 7: Rekabet İhlali İle İlgili Dava Dosyalarının Verilen Kararlara Göre Dağılımı

\begin{tabular}{|l|l|l|l|}
\hline & Kategoriler & Sayı & $\%$ \\
\hline \multirow{4}{*}{ Dava Sonucu } & Oy Birliği (Ret) & 17 & 68,0 \\
\cline { 2 - 4 } & Oy Çokluğu (Ret) & 2 & 8,0 \\
\cline { 2 - 4 } & Oy Birliği (Kabul) & 4 & 16,0 \\
\cline { 2 - 4 } & Oy Çokluğu (Kabul) & 2 & 8,0 \\
\cline { 2 - 4 } & Toplam & 25 & 100,0 \\
\hline
\end{tabular}


Araștırma verilerinden elde edilen sonuçlara göre, Türkiye'deki televizyon yayıncılığı sektöründe rekabet ihlali ile ilgili Rekabet Kurumu'na açılan davaların \%76'sı oy birliği ya da oy çokluğu ile reddedilmiş, \%24'ü de oy birliği ya da oy çokluğu ile kabul edilmiștir (Tablo 7). Bu doğrultuda her ne kadar kurumlar hakkında şikayetlerde bulunulmuş olsa da suç işleme oranının ya da diğer bir ifadeyle rekabeti ihlal etme oranının \% 25'ten dahi düşük olduğu görülmektedir.

$\mathrm{Bu}$ durum Rekabet Kurumu'nun sektördeki denetleyici ve düzenleyici bir kurul olarak fonksiyonu incelendiğinde almış olduğu kararların ne denli önemli olduğunu ortaya çıkarmaktadır. Rekabet ihlallerini engellemek, rekabet ortamını tesis etmek ve bunu denetlemekle yükümlü olan Rekabet Kurumu, hem aldığı önlemler hem de davalarda verdiği kararlarla rekabetin zarar görmesini engellemektedir. Rekabet Kurumu'nun, soruşturma yapılmasını uygun gördüğü dosyalarda ceza alanlar incelendiğinde, söz konusu dosyalara konu olanlar arasında \%83'ünün özel yayın kuruluşları, \%17'sinin ise Türkiye Futbol Federasyonu olduğu görülmüștür. Burada özel yayın kuruluşlarının tamamı idari para cezası alırken, Türkiye Futbol Federasyonu'nun hiç bir soruşturmadan ceza almadığı tespit edilmiştir.

\section{Tartışma ve Sonuç}

Türkiye'de yaklaşık 50 yıl önce başlayan televizyon yayıncılığında, 21 yıllık süre zarfında tek kanal (TRT) ile yayın yapılmıştır. Ancak 90’lı yılların başında özel kanalların da yayın yapmasına imkan verilmesi ve akabinde birçok özel televizyon kanalının kurulup yayın yapmaya başlaması Türk televizyon yayıncılığında büyük bir dönüşümün yaşanmasına neden olmuştur. Özel kanalların birbiri ardına yayın yapması ve halkın bu kanallara ilgi göstermesi beraberinde reyting ve reklam unsurlarının önem kazanmasına yol açmıştır. En büyük gelir kaynağı reklam olan bu özel televizyon kanalları varlıklarını daim kılmak ve daha fazla gelir elde etmek için birbirleriyle rekabet etmeye başlamıştır. Televizyon kanalları arasında yaşanan bu rekabet, herhangi bir yasal düzenlemenin ya da denetim mekanizmasının olmaması hasebiyle birçok rekabet ihlalinin gerçekleşmesine sebebiyet vermiştir. Bu rekabet ihlalleri televizyon kanalları arasında önemli boyutlarda hak kayıplarının meydana gelmesine neden olmuştur.

Türk televizyon yayıncılığında meydana gelen rekabet ihlalleri neticesinde radyo ve televizyon faaliyetlerini düzenlemek ve denetlemek için 1994 yılında Anayasanın 133. maddesi kapsamında üyeleri TBMM Genel Kurulunca seçilen, özerk ve tarafsız bir kamu tüzel kişiliği olarak Radyo Televizyon Üst Kurulu (RTÜK) kurulmuştur. Bununla birlikte yine aynı yıl Sanayi ve Ticaret Bakanlığı'nda oluşturulan bir komisyon tarafından kanun tasarısı hazırlanmıș ve 4054 nolu Rekabetin Korunması Hakkında Kanun yürürlüğe girmiştir. Bu kanun yürürlüğe girdikten sonra ise 1997 yılında bu kanunu uygulamakla yükümlü otorite olan Rekabet Kurumu kurulmuştur. Rekabet Kurumu, kurulduğu tarih ele alındığında iki önemli sorunun çözüme kavuşmasını sağlamıştır. Öncelikle kurum, televizyon yayıncılığı sektöründe 7 yılık süreçte meydana gelen rekabet ihlallerinin sona ermesi için denetimleri yapmış ve rekabet kanununu uygulayarak sektörde hakim bir kurum olduğunu ispat etmiștir. Bunun haricinde gelişen teknoloji ile birlikte gerekli yasal zemini hazırlayarak televizyon kanallarının, televizyon sahiplerinin ve işbirlikçi unsurların/firmaların şimdi ve gelecekte rekabeti ihlal etmelerinin önüne geçmeye çalışmıştır. Bu özellikleriyle Rekabet Kurumu, Türk televizyon yayıncılığında rekabeti tesis eden bir kurum olup televizyon yayıncılığı sektöründe rekabet ihlallerini engelleyerek 
mevcut bir sorunun çözüme kavuşmasını sağlamış aynı zamanda doğabilecek sorunların da önüne geçmiştir.

Bu noktadan hareketle, Türkiye'deki televizyon yayıncılığında rekabet ihlali ile ilgili Rekabet Kurumu'na yapılan şikayetleri incelemek ve Rekabet Kurumu tarafindan alınan kararların televizyon yayıncılığı sektörüne katkısının ne olduğunu tespit etmek amacıyla bir araştırma yapılmıştır. Yapılan çalışmadan elde edilen sonuçlara göre, 1994 yılında yürürlüğe giren 4054 nolu Rekabetin Korunması Hakkında Kanun, yürürlüğe girdiği yıldan bugüne kadar Türk televizyon yayıncılı̆̆ı sektöründe rekabetin korunması noktasında etkili ve caydırıcı bir rol üstlenmiştir. Rekabetin Korunması Hakkında Kanun'un yürürlüğe girmesinden sonra kurulan ve bu kanunu uygulamakla yükümlü otorite olan Rekabet Kurumu ise yapmış olduğu denetimlerle, almış olduğu kararlarla ve getirmiş olduğu düzenlemelerle Türk televizyon yayıncılığı sektöründe rekabetin tesis edilmesinde ve korunmasında etkin bir göreve sahip olmuştur. Çünkü Türkiye'deki ulusal, bölgesel ve yerel televizyon kanalları ve bu kanallarla ilişkili olan kurum ve kuruluşlar, rekabetin ihlal edildiği durumlarda yetkili merci olarak Rekabet Kurumu'na şikayette bulunmakta ve onun aldığı kararlara riayet etmektedir. Bununla birlikte Rekabet Kurumu'nun yaptırımlarının ve 4054 sayılı kanunun getirmiş olduğu yasakların caydırıcı etkisinden ötürü, bu televizyon kanalları çoğunlukla rekabeti ihlal eden eylemlerden kaçınmaktadır. Öyle ki, 1999 yılından 2018 yılına kadarki süre zarfında Rekabet Kurumu'na rekabetin ihlali ile ilgili sadece 25 şikayet gelmiş ve bunların da sadece 6 tanesinde rekabetin ihlal edildiği görülmüștür. Bu nedenle çalışmada yer alan "Rekabet Kurumu, televizyon yayıncılığı sektöründe rekabet sürecini denetleyici ve düzenleyici bir rol üstlenmektedir" hipotezi doğrulanmaktadır.

Rekabet ihlalleri ile ilgili Rekabet Kurumu'na gelen şikayetlerin dörder yıllık süre zarfında dağılımına bakıldığında ise şikayet sayılarının hemen hemen eşit olduğu görülmektedir. Türkiye'de Rekabet Kurumu'na her dört yılda bir ortalama 5 tane rekabet ihlali davası açılmaktadır. Bu davaların \%72,5 gibi çok büyük bir oranını şirketler açmıştır. Aynı şekilde rekabet ihlali ile ilgili şikayet edilen tarafın da yine \%76,1 ile en fazla özel kanallar olduğu görülmektedir. Televizyon yayıncılı̆̆ında özel kanalların en büyük hedefi sektörde hakim duruma gelmek ve dolayısıyla daha fazla kazanç elde etmektir. Bu kazancın en fazla sağlandığı nokta ise reklamlardır. Bu nedenle özel kanalların daha fazla reklam geliri elde etmek için daha fazla izlenme oranına sahip olmaları gerekmektedir. Bu doğrultuda daha fazla gelir elde etmek ve rekabette geri kalmak istemeyen özel kanalların, rekabeti ihlal eden eylemlerde bulunabildiğini ve kamu yararını göz ardı edebildiklerini ifade etmek mümkündür. Özel kanalların aksine, devlete ait olan organlar (RTÜKveTRT) kamu yararını gözettiği için rekabeti ihlal eden eylemlerden kaçınmaktadır. Öyle ki, 19 yıllık süreçte TRT ve RTÜK hakkında rekabetin ihlal edilmesi ile ilgili sadece üç soruşturma açılmıştır ve bu soruşturmaların üçünde de rekabetin ihlal edilmediği sonucuna varılmıştır. Bu verilerden yola çıkarak çalışmada yer alan "Rekabet ihlali ile ilgili şikayet edilenler daha çok özel kanallardır" hipotezi doğrulanmış bulunmaktadır.

Türkiye'deki televizyon yayıncılığında rekabet ihlali ile ilgili Rekabet Kurumu'na açlan davalar incelendiğinde, dava dosyalarının büyük bir kısmının (\%60) en fazla 14 sayfa olduğu görülmektedir. Rekabet ihlali ile ilgili açılan bir davada birden fazla şikayetçi, birden fazla şikayet edilen ve birden fazla şikayet olabilmektedir. Bu sebeple, davada tarafların ve şikayet edilen konuların sayısı arttıkça ve rekabet 
ihlalinin gerçekleşmiş olması muhtemel ise davaların sayfa sayıları da artış göstermektedir. Bu davalarda yer alan sayfaların bazıları açık ve şeffaf olarak halka gösterilmekte, bazıları da tarafların istekleri doğrultusunda eğer uygun görülürse "gizli" ibaresi konularak gizlenmektedir. Bu doğrultuda açllan davaların alenilik oranına bakıldığında, dava dosyalarının \%64'ünün tamamen yayınlandığı, \%36'sının ise bazı sayfalarının/kısımlarının gizlendiği tespit edilmiştir. Bu gizlenen sayfaların bazılarında Rekabet Kurumu'nun kendi adına gizlediği tek nokta, davayı açan Rekabet Kurumu uzmanının kim olduğudur. Bunun haricinde Rekabet Kurumu kendi adına herhangi bir gizliliğe başvurmamaktadır. Rekabet Kurumu, rekabet ihlalleri ile ilgili dosyaların tamamını internet sitesi aracılığıyla şikayet edenleri, edilenleri, rekabet ihlallerine dair uzmanların hazırladıkları raporları ve karar dosyaları ile kararlardaki karşıt görüşleri de dahil etmek üzere insanlar ile paylaşmıştır. $\mathrm{Bu}$ durum ise, çalışmada öne sürülen "Rekabet Kurumu, şeffaflık ve alenilik ilkesine göre hareket etmektedir" hipotezini doğrular niteliktedir.

Özetle çalışmada, Türkiye'deki televizyon yayıncılığı sektöründe rekabet ihlalinin az sayıda vuku bulduğu, rekabet ihlallerini engelleme noktasında Rekabet Kurumu'nun çok önemli ve etkili bir görev üstlendiği, Rekabet Kurumu'nun sektörde düzenleyici ve denetleyici bir role sahip olduğu, rekabet ihlali ile ilgili şikayet edilenlerin çoğunlukla özel kanallar olduğu ve açılan davalarda Rekabet Kurumu'nun şeffaflık ve alenilik ilkesine göre hareket ettiği sonucuna varılmıştır.

\section{Kaynakça}

Edgü, E. (1967). Ticaret Hukuku I Umumi Hükümler. Ankara: Sevinç Matbaası.

Mevzuatı Geliştirme ve Yayın Genel Müdürlüğü (2018). Türkiye Cumhuriyeti Anayasası. http://www.mevzuat.gov.tr/MevzuatMetin/1.5.2709.pdf, Erişim Tarihi: 12.03.2018.

Pereira, M. M. (2003). Vertical and Horizontal Integration in the Media Sector and EU Competition Law. European Commission - Competition DG. Brussels.

Rekabet Kurumu (2018a). Rekabetin Korunması Hakkında Kanun. https:// www.rekabet.gov.tr/tr/Sayfa/Mevzuat/4054-sayili-kanun, Erişim Tarihi: 15.03.2018.

Rekabet Kurumu (2018b). Rekabet Kurumunun Kurumsal Yapısı Hakkında. https://www.rekabet.gov.tr/tr/Sayfa/Kurumsal/hakkimizda, Erișim Tarihi: 24.01.2018.

Sanlı, K. C. (2000). Rekabetin Korunması Hakkındaki Kanun'da Öngörülen Yasaklayıcı Hükümler ve Bu Hükümlere Aykırı Sözleşme ve Teşebbüs Birliği Kararlarının Geçersizliği. Ankara: Rekabet Kurumu Yayınları.

Sayllgan, E. (2009). Medya Sektöründe Rekabet Olgusu ve Medyaya Giriş Engelleri. Marmara İletişim Dergisi, Sayı 15, s. 79-89.

Stern (2018). 1890 The Sherman Antitrust Act. http://www.stern.nyu.edu/networks/ ShermanClaytonFTC_Acts.pdf, Access Date: 06.02.2018.

Şafak, A. (1992). Hukuk Terimleri Sözlüğü. Ankara: Rehber Yayıncılık. 
Türkiye Cumhuriyeti Dışişleri Bakanlığı (2018). Türkiye ile Avrupa Ekonomik Topluluğu Arasında bir Ortaklık Yaratan Anlaşma (Ankara Anlaşması) -12 Eylül 1963. http://www.mfa.gov.tr/turkiye-ile-avrupa-ekonomik-topluluguarasinda-bir-ortaklik-yaratan-anlasma-_ankara-anlasmasi_-12-eylul-1963-. tr.mfa, Erişim Tarihi: 16.01.2018.

Utton, M. A. (2003). Market Dominance and Antitrust Policy. Cheltenham: Edward Elgar Publishing. 